\title{
Application of modern innovative technologies in foreign languages teaching
}

\author{
A. M. Trotsiuk, O. V. Yasinska
}

Lesya Ukrainka Volyn National University, Lutsk, Ukraine

*Corresponding author: oyas@vnu.edu.ua, oyas@bigmir.net

Paper received 24.12.20; Accepted for publication 02.02.21.

\author{
https://doi.org/10.31174/SEND-Ph2021-248IX73-25
}

\begin{abstract}
The given article focuses on the application of modern innovative technologies in foreign languages teaching. The authors provide the advantages and disadvantages of computerized learning of foreign languages, traditional tools of educational control activities, new multimedia tools and programs. This article highlights the general problems of distance learning implementation: technical and methodological. Also, the authors identified some specific modern innovative technologies in teaching foreign languages problems. The authors investigate the issue of determining the effectiveness of distance learning in the framework of university disciplines "Foreign languages" in the light of the modern educational standard. The authors of the given article prove that the main problem in learning foreign languages through distance learning is the lack of direct contact with the teacher, associated in most cases not only with technical difficulties, but also with methodological ones (effective organization of group and individual work with students, competent and effective presentation of information material and check its assimilation). The authors propose a tool for the formation of an individual educational direction of a student in the light of personal educational goals.
\end{abstract}

Keywords: innovative technologies, educational computer programs, computerized learning, foreign languages, distance learning.

In universities the preference is given to active teaching methods, which are aimed at forming students' independence, flexibility, variability and critical thinking. The most powerful source of students' cognitive activity, the development of their intellectual factors today there are new innovative technologies.

Innovative technologies in education are primarily informational and communicational technologies that are inextricably linked to the use of computer-based learning.

The main issues in the application of innovative technologies are the structure of educational computer programs, their content and the optimal organization of the Web-space.

According to the pyramid of knowledge development, which have been developed by American scientists in the 80 's in the twentieth century, 75\% of information is assimilated through learning through use simulation and game methods. This is especially important when teaching non-professional disciplines students do not prepare as carefully as for professionals. These data are fully confirmed research of modern Ukrainian scientists. According to their estimates, a person can, reading with his eyes, remember $10 \%$ of information, listening - $26 \%$, viewing $30 \%$, listening and viewing $-50 \%$, discussing - $70 \%$, personal experience allows you to learn $80 \%$ of the information shared activities with discussion - 90\%, teaching others - $95 \%$ [5, p. 846].

There is a tendency to actively use distance learning in quarantine restrictions, which effectively solves this problem by providing constant and sufficiently dynamic telecommunications communication between teacher and student at a distance, students with each other and with native speakers during the learning process, and initiating this communication is possible any of these subjects of the educational process [8].

The main means of distance learning English is an electronic textbook, the material of which must be concluded taking into account the principles programmable management of the learning process. Such a textbook should ensure the implementation of the leading didactic principles, namely clarity, consciousness, activity, systematicity, consistency, accessibility, strength of learning, etc., as well as meet the requirements of a personalityoriented approach in foreign language teaching methods [8].

Control in distance learning of foreign languages can be carried out in the form of tests, control translation and oral communication with the teacher. Moreover, in the case of the test, the verification and evaluation of answers are carried out automatically by the distance learning system. The transition to distance learning should be gradual and well thought out. Such a proposal seems balanced and logical, because, firstly, it will provide a gradual habituation to a new form of learning as teachers and students, and secondly, some elements of distance learning can be successfully used in the preparation of full-time and parttime students, especially taking into account the tendency to reduce hours for classroom classes with their subsequent compensation through independent and individual student work [7]. Third, this approach will give scientists enough time to develop appropriate distance courses, which will improve the quality of the latter and help avoid many technical problems [7].

Thus, one of the first attempts to introduce elements of distance learning may be to advise students by e-mail or via Skype instead of or in addition to the traditional faceto-face consultation within the walls of a higher education institution. It is advisable to organize independent work of students using elements of distance learning. Students can send completed tasks by e-mail, which is very convenient and avoids additional costs.

Another example of the introduction of elements of distance education in full-time and part-time departments is the use of the Moodle system, which allows teachers to create their own online courses and manage site content. This system offers a variety of ways to provide training material, knowledge testing and performance monitoring. For full-time and part-time students, this program will be useful in learning new vocabulary and developing reading, listening and writing skills, in particular, it is advisable to place additional exercises for better learning, grammar and lexical tests, as well as tests for listening, reading and writing. These elements of distance learning greatly facilitate the control of students' learning activi- 
ties, as they allow you to track the work of each student individually and the quality of its implementation, as well as encourage students to work more effectively. This significantly saves teacher time due to automatic verification [7]. Thus, distance learning has a number of advantages, and the use of some of its elements can contribute to the effectiveness of full-time and part-time students. The development of distance learning courses is a complex and long process that requires painstaking work and the development of a significant theoretical basis.

It should be also mentioned that the quality of students learning in classrooms with a teacher is much more productive and effective than through applications. However, in today's world, the pandemic of Covid-19 interactive online learning is gaining popularity. Advantages the use of interactive online learning systems is accessibility, flexibility, absence of stress, quality of training, personal counselling, choice of time and place for learning, saving free time, improving computer skills.

Among the methods of interactive online learning in the teaching of non-professional disciplines

can be distinguished the following:

Podcasting is a way to publish media streams (usually audio or video) world wide web (usually in MP3 format), which are announced in a special way that allows automate the download of new releases to the download device. For convenience podcast playback created software that regularly queries a website on

subject to new entries, which are then downloaded to the user's computer.

Video files. With the help of video files, students better master the study material than when they just read or hear it.

Blogging. A blog is a type of site that is filled with text from time to time and multimedia information, and the latest blog entries are displayed in reverse in chronological order. Students have the opportunity to express their views on that article posted, and the teacher to make some changes in the content, if necessary, thanks quick feedback. The learning management system is specially designed for online learning. This system allows the teacher to create, place and control complete the course assignment, send homework and enroll students in the course. This system allows the teacher to create, place and control complete the course assignment, send homework and enroll students in the course.

Students can complete assignments online or download, make and submit it to the teacher's e-mail for verification [5, p. 552].

The problems of innovative technologies are dealt with by such researchers as

N. Basova [1], M. Clarin [6], I. Pidlasyi [9], I. Dychkivska [2], D. Drozdovskyi [3], M. Kademiya [4], T. Stefanenko [11], Ye. Polat [10].

The use of automated training courses for the study of foreign languages, especially English, is constantly spreading in Ukrainian universities.

The method of using computers in teaching foreign languages has proved to be a promising direction. Traditional forms of educational control activities: written test, oral examination, dictation, essay, translation and exam are not objective enough, accurate and operational. Computerized foreign languages learning allows you to moni- tor the student's learning activities with high accuracy and objectivity, providing constant feedback.

New multimedia tools that apply an audiovisual format provide opportunities that traditional textbooks cannot provide. The availability of such tools helps teachers to plan activities that bring an element of interest to the learning process. They make it possible to create an active, managed, communicative environment in which learning takes place. In this way, the student's interaction with the computer from the simple exchange of information or execution of commands becomes a multifaceted activity in this environment, which opens up truly unlimited opportunities for the student.

Computerized learning of foreign languages has many advantages, including:

- variability of application at different stages of training;

- the possibility of application at any stage of work in practice;

- educational material is better perceived and easier to remember by students;

- economical use of the educational process;

- individualization of training, determination of depth and sequence of mastering, pace of work;

- registration of student data;

- collection and processing of statistical data on individual activities of students;

- reduction of types of work that cause student fatigue;

- use of various audiovisual teaching aids (graphics, sound) to enrich and motivate learning, visual and dynamic presentation of material;

- branching of the learning sequence based on the analysis of student errors;

- adaptation of available educational materials to computerized learning conditions;

- creating a comfortable learning environment;

- introduction of experimental research;

- intensification of student learning activities;

- intensification of training and increase of the level of motivation;

- formation of students' self-esteem and creation of conditions for independent work.

However, it should be kept in mind that the unjustified application computerized learning of foreign languages tools in the educational process can be not only ineffective, but also harmful. It is important to understand that the use of computers has certain disadvantages:

- computers do not provide certain important features of real communication;

- some students find it difficult to get used to independent (from the teacher) work;

- computers do not give a sense of cooperation, as in the case of working with a teacher;

- undisciplined students have difficulty working with computers;

- some students / teachers do not perceive a departure from traditional teaching methods;

- computers are machines that require maintenance and can stop working at any time;

- reading text from the screen is more tiring than reading printed text.

Modern computerized learning of foreign languages with the application of multimedia programs significantly 
expands and diversifies the program of studying foreign languages in universities, provides access to a variety of authentic materials (computer presentation of language material based on fiction, articles, information sites; work with a dictionary, etc.), encourages students to learning foreign languages, expands the motivation of students to learn, giving them the individualization of learning and effective mastery of a foreign language.

\section{REFERENCES}

1. Бистрова Ю. В. Інноваційні методи навчання у вищій школі України [Електронний ресурс] / Ю. В. Бистрова// Право та інноваційне суспільство: електрон. наук. вид. 2015. - №1 (4). - Режим доступу: http://apir.org.ua/wpcontent/uploads/2015/04/Bystrova.pdf.

2. Дичківська I. М. Інноваційні педагогічні технології: навч. посіб. / Ілона Миколаївна Дичківська. - К.: Академвидав, 2004. - $352 \mathrm{c}$.

3. Дроздовський Д.І. Виклики й перспективи реформування сучасної освіти в Україні / Дмитро Ігорович Дроздовський //Дивослово. - 2018. - № 1. - С. 2 -6.

4. Кадемія М. Ю. Дистанційне навчання у віртуальному університеті /М. Ю. Кадемія, В. О. Уманець// Відкрите оствітнє е-середовище сучасного університету. - 2016. № 2. - C. 47-51.

5. Карамушка Л.М. Рольова гра / Людмила Миколаївна Карамушка // Енциклопедія освіти / Акад. пед. наук України; гол. ред. В.Ф. Кремень. - К.: Юрінком Інтер, 2008. - $1040 \mathrm{c}$.

6. Кларин Н.В. Инновационные модели обучения: Исследо-

вание мирового опыта. Монография. - М.: Луч, 2016. $640 \mathrm{c}$.

7. Концепція розвитку дистанційної освіти в Україні [Електронний ресурс]. - Режим доступу: http://www.osvita.org.ua/distance/pravo/00.html

8. Олійник О.В. Інноваційні технології дистанційного навчання іноземної мови для студентів немовних ВНЗ /Олександр Васильович Олійник // Лінгвістичні дослідження: зб. наук. праць ХНПУ імені Г.С. Сковороди. - 2014. - Вип. 38. - С. 238-246.

9. Підласий І.П. Педагогічні інновації/ І.П. Підласий// Рідна школа. - 1998. - № 12. - С.34.

10. Полат Е.С. Новые педагогические и информационные технологии в системе образования Е.С. Полат. - М.: Асаdemia, 2000. $-271 \mathrm{c}$.

11. Стефаненко П. Теоретичні i методичні основи дистанційного навчання у вищій школі. Дисертація докт. пед. наук: 13.00.04 / Ін-т пед. і псих. АПН України. - К., 2002. $-490 \mathrm{c}$.

\section{REFERENCES TRANSLITERATED}

1. Bystrova Yu.V. Innovatsiyni metody navchannya u vyshchiy shkoli Ukrayiny [Innovative teaching methods in higher education in Ukraine] [elektronnyy resurs]/ Yu.V. Bystrova// Pravo ta innovatsiyne suspilstvo: elektronno-naukove vydannya. - 2015. - № 1(4). - Rezhym dostupu: http://apir.org.ua/ wp-content/uploads/2015/04/Bystrova.pdf.

2. Dychkivska I.M. Innovatsiyni pedahohichni technolohiyi [Innovative pedagogical technologies]: navchalnyy posibnyk/ Ilona Mykolayivna Dychkivska. - K.: Akademvydav, 2004. $352 \mathrm{~s}$.

3. Drozdovskyy D.I. Vyklyky i perspektyvy reformuvannya suchasnoyi osvity v Ukrayini [Challenges and prospects of reforming modern education in Ukraine]/ Dmytro Ihorovych Drozdovskyy// Dyvoslovo. - 2018. - № 1.- S. 2 - 6.

4. Kademiya M.Yu. Dystantsiyne navchannya u virtualnomu universyteti [Distance learning in a virtual university]/ M.Yu. Kademiya, V.O. Umanets// Vidkryte osvitnye seredovyshche suchasnoho universytetu. - 2016. - № 2. - S. $47-51$.

5. Karamushka L.M. Roliovva hra [Role play]/ Liudmyla Mykolaivna Karamushka// Entsiklopediya osvity/ Akademiya Pedahohichnykh Nauk Ukrainy; holovnyy redaktor V.F. Kremen/ - K.: Yurinkom Inter, 2008. - 1040 s.

6. Klarin N.V. Innovatsyonniye modeli obucheniya: issledovaniya mirovoho opyta [Innovative learning models: a study of world experience] Monografiya. - M.: Luch, 2016. - 640 s.

7. Kontseptsiya rozvytku dystantsijnoyi osvity v Ukrayini [The concept of distance education development in Ukraine] [Elektronnyy resurs]. - Rezhym dostupu: http://www.osvita.org.ua/distance/pravo/00.html

8. Oliynyk O.V. Innovatsiyni tekhnolohiyi dystantsiynoho navchannia inozemnykh mov dlia studentiv nemovnykh spetsialnostey VNZ [Innovative technologies of distance learning of a foreign language for students non-language in higher educational establishments]/ Oleksandr Vasyliovych Oliynyk// Linhvistychni doslidzhennya: zbirnyk naukovykh prats Kharkivskoho natsionalnoho pedahohichnoho universytetu imeni Hryhoriya Savycha Skovorody. - 2014.- Vypusk 38. S. $238-246$

9. Pidlasyy I.P. Pedahohichni innovatsiyi [Pedagogical innovations]/ I.P. Pidlasyy// Ridna shkola. - 1998. - № 12. - S.34.

10. Polat Ye.S. Novyye pedahohicheskiye i informatsionnyye tekhnolohiyi $\mathrm{v}$ sisteme obrazovaniya [New pedagogical and informational technologies in system of education]/ Ye.S. Polat. - M.: Academia, 2000. - $271 \mathrm{~s}$.

11. Stefanenko T. H. Teoretychni i metodychni osnovy dystantsiynoho navchannya u vyshchiy shkoli [Theoretical and methodical bases of distance learning in higher school]. Dysertatsiya doktora pedahohichnykh nauk: 13.00.04/ Instytut pedahohiky i psykholohiyi Akademiyi Pedahohichnykh Nauk Ukrayiny. - K., 2002. - 490 s. 